\title{
Total Phenol and Antioxidant Activity of Ethanol Extract and Water Extract from Claw Uncariaa gambir Roxb
}

\author{
(Total Fenol dan Aktivitas Antioksidan Ekstrak Etanol dan Ekstrak Air dari Cakar Uncaria \\ gambir Roxb)
}

\author{
Lucky Hartanti $^{\left.1^{*}\right)}$, Asri Mulya Ashari ${ }^{1}$, Warsidah ${ }^{2}$ \\ ${ }^{1}$ Fakultas Pertanian Universitas Tanjungpura Pontianak \\ ${ }^{2}$ Fakultas Matematika dan Ilmu Pengetahuan Alam, Universitas Tanjungpura Pontianak. \\ Jl. Prof. Dr. Hadari Nawawi Pontianak.
}

\section{ABSTRACT}

Uncaria gambier Roxb is a plant from the Rubiaceae family, belongs to the Bajakah group and has been used empirically in the treatment of various types of diseases in the community. Besides being one of the industrial plants and export commodities produced in Sumatra and Kalimantan, gambier leaves is also used frequently in Indonesia, both for the pharmaceutical and cosmetic industries. As a result, market demand both nationally and internationally have increased. The aim of this research are determination of antioxidant activity of ethanol extract and aqueous extract of gambir claw using 1,1-diphenil-2-picrylhydrazyl (DPPH) and determination of total phenol using Calcetau folin reagent. Gambier plant samples were taken in the forest area around the Tanjungpura University campus, the claws were separated and dried at room temperature, then powdered and extracted by maceration using $70 \%$ ethanol pa and aquadest, then the extract was concentrated until it was ready to be tested for antioxidant activity and determination of total phenol. The total phenolic ethanol extract and aqueous extract of gambir claw were 224.66 mg GAE/g extract (GEA : Gallic Acid Eqivalent) and $299.08 \mathrm{mg}$ GAE/g extract, respectively, while the antioxidant potential (IC50) was $39.566 \mu \mathrm{g} / \mathrm{mL}$ and $65.140 \mu \mathrm{g} / \mathrm{mL}$, and the IC50 for comparison of Vitamin C was $7.02 \mu \mathrm{g} / \mathrm{mL}$.

Uncaria gambir Roxb adalah tanaman dari family Rubiaceae, termasuk dalam golongan bajakah dan telah digunakan secara empiris dalam pengobatan berbagai jenis penyakit di masyarakat. Selain telah menjadi salah satu tanaman industri dan komoditas eksport yang dihasilkan di wilayah Sumatera dan Kalimantan, pemakaian gambir secara nasional khususnya daun gambir juga sangat besar, baik untuk kebutuhan industri obat-obatan maupun kosmetik, akibatnya permintaan pasar baik nasional maupun dunia mengalami peningkatan. Penentuan aktivitas antioksidan dari ekstrak etanol dan ekstrak air dari cakar gambir menggunakan 1,1-diphenyl-2pikrilhidrazil (DPPH) serta penentuan fenol total menggunakan pereaksi folin Calcetau. Sampel tanaman gambir diambil di daerah hutan sekitar kampus Universitas Tanjungpura, dipisahkan bagian cakarnya dan dikeringkan pada suhu kamar, lalu diserbukkan dan diekstraksi secara maserasi masing-masing dengan menggunakan etanol p.a 70\% dan akuadest, selanjutnya ekstrak dipekatkan sampai siap untuk dilakukan pengujian aktivitas antioksidan dan penentuan total fenol. Total fenol ekstrak etanol dan ekstrak air dari Cakar gambir masing-masing sebesar sebesar 224,66 mg GAE/g ekstrak and $299.08 \mathrm{mg}$ GAE/g ekstrak sedangkan potensi antioksidan (IC50) sebesar $39.566 \mu \mathrm{g} / \mathrm{mL}$ dan $65.140 \mu \mathrm{g} / \mathrm{mL}$, dan IC50 pembanding Vitamin C adalah $7.02 \mu \mathrm{g} / \mathrm{mL}$.

Keywords: IC50, Uncaria gambir Roxb, antioxidant, total phenol, Gallic acid eqivalent.

*)Corresponding author:

Lucky Hartanti

E-mail: lucky.hartanti@faperta.untan.ac.id

\section{PENDAHULUAN}

Radikal bebas menyebabkan beberapa kerusakan pada tubuh yang mengganggu metabolisme sel, serta mampu mengubah lipid, protein, dan DNA sebagai sasaran utama [1]. Lipid rentan terhadap radikal bebas yang mengakibatkan peroksidasi lipid dan dapat menyebabkan hilangnya aktivitas enzim. Kerusakan yang terjadi pada protein dapat mengakibatkan denaturasi protein oksidatif dan kerusakan DNA yang menyebabkan mutagenesis dan karsinogenesis [2]. Kedua hal ini telah terlibat dalam berbagai jenis penyakit manusia seperti radang sendi, kerusakan sel, 
rheumatoid arthritis, diabetes mellitus dan penuaan dini [3].

Spesies oksigen reaktif atau diistilahkan dengan Reactive Oxygen Species (ROS) telah menjadi petunjuk dalam perkembangan beberapa penyakit. Pembentukan ROS adalah proses umum selama terjadinya metabolisme sel. Spesies oksigen aktif yang paling penting antara lain adalah radikal hidroksil, radikal amnion superoksida, dan oksigen singlet [4]. Stres oksidatif ditemukan sebagian besar terjadi pada jaringan adiposa yang merupakan sumber utama pembentukan ROS [5]. Keberadaan ROS yang berlebihan dalam tubuh akan menyebabkan stres oksidatif dan mempercepat proses penuaan [6].

Antioksidan adalah zat penting dan memainkan peran pencegahan yang potensial untuk melindungi tubuh dari kerusakan yang terkait dengan stres oksidatif oleh radikal bebas [7]. Zat ini juga dapat menghambat terjadinya oksidasi lipid dan biomolekul lainnya dengan menghalangi langkah inisiasi dan menampung berbagai radikal bebas untuk proses detoksifikasi organisme [8]. Kecukupan antioksidan merupakan benteng pertahanan untuk mencegah dampak buruk dari ROS terhadap jaringan tubuh [6].

Beberapa penelitian tentang antioksidan telah dilakukan dalam mendapatkan senyawa aktif dari tumbuhan dengan aktivitas yang beragam seperti antioksidan, antibakteri dan antikanker. Bajakah adalah istilah untuk akar dari tumbuhan tertentu yang tumbuh di hutan-hutan Kalimantan dan telah banyak digunakan secara empiris dalam pengobatan berbagai macam penyakit seperti kencing manis (diabetes mellitus), jantung, kolesterol dan kanker. Genus Uncaria merupakan salah satu jenis bajakah yang secara turun temurun telah digunakan dalam kehidupan masyarakat khususnya di wilayah Kalimantan, untuk pengobatan berbagai penyakit seperti kanker, antibakteri, dan penyakit kulit. Penelitian sebelumnya tentang Uncaria antara lain ekstrak etanol dari cakar bajakah Uncaria tomentosa (Wild ex Schultz) memiliki aktivitas antibakteri dan antiinflamasi [9] dan potensi sitotoksik ekstrak etanolnya (LC50) sebesar 21,754 ppm [10]. Bajakah merah (Spatholobus littoralis Hassk) dari Kalimantan

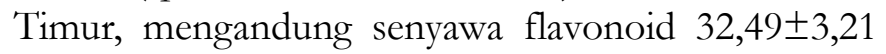
ppm, sedangkan kulit bajakah putih mengandung senyawa fenolik 163,88 $\pm 74,75$ ppm. Aktivitas antioksidan akar bajakah merah dikategorikan sangat kuat (26,29 ppm). Ekstrak etanol akar bajakah merah
(Spatholobus littoralis Hassk) asal Kalimantan Tengah menunjukkan aktivitas antioksidan tinggi yaitu sebesar 8,25 ppm [11] dan memiliki aktivitas antibakteri Escherichia coli dengan konsentrasi hambat minimum sebesar 6,25 [12].

U. gambir Roxb adalah salah satu tanaman dari family Rubiaceae yang bernilai ekonomi tinggi karena kandungan kimia antara lain katekin, pirokatekol, flouresin, sampuran lilin serta minyak pada ekstrak daun dan ranting batangnya [13]. Uncaria gambir Roxb tergolong dalam jenis akar atau kayu bajakah. Secara tradisional, gambir telah digunakan dalam pengobatan berbagai penyakit, dan untuk beberapa daerah tertentu dijadikan sebagai bahan menyirih yang bertujuan untuk menguatkan dan menghindarkan gigi dari rasa sakit. Tanaman ini merupakan komoditas eksport sehingga menjadi tanaman unggulan di beberapa wilayah terutama di Sumatera dan Kalimantan dan Nusa Tenggara. Kebutuhan gambir terutama daunnya baik dalam negeri maupun pasar internasional sebagai bahan baku kosmetik dan sediaan farmasi makin tinggi, seiring dengan makin giatnya penelitianpenelitian tentang kandungan dan aktivitasnya dalam bidang kesehatan. Cakar gambir adalah bagian dari $U$. gambir yang tumbuh di sekitar ketiak daun dan ketiak ranting, dengan bentuk yang melengkung dan berujung runcing. Belum ada informasi ilmiah tentang kandungan dan aktivitas secara spesifik dari cakar gambir.

Beberapa pengujian antioksidan dari ekstrak daun U. gambir menggunakan 1,1- diphenyl-2-picrylhydrazy (DPPH) menunjukkan nilai IC50 dari daun U. gambir yang bervariasi. Sazwi dkk [13] melaporkan aktivitas antioksidan ekstrak daun U. gambir yang sangat kuat yaitu IC50 sebesar $6,4 \mu \mathrm{g} / \mathrm{mL}$ sedikit lebih besar daripada nilai IC50 pembandingnya sebesar 4,8 $\mu \mathrm{g} / \mathrm{mLngan}$ metode yang sama, Amir dk.k [14] melaporkan antioksidan daun U. gambir yaitu IC50 sebesar 18,27 $\mu \mathrm{g} / \mathrm{mL}$ sedangkan oleh Anggraini, dkk [15] melaporkan antioksidan daun U. gambir diperoleh IC sebesar $92-93.1 \%$ dan IC50 sebesar $25,5 \mu \mathrm{g} / \mathrm{mL}$ dilaporkan oleh Melia, dkk [16].

Dalam penelitian ini, penentuan total fenol dan kemampuan/potensi antioksidan dilakukan pada ekstrak etanol dan ekstrak air dari cakar yang tumbuh di ketiak ranting dan daun $U$. gambir yang secara empiris telah digunakan sebagai afrodiasak dan anti penuaan dini oleh masyarakat Kalimantan Barat. Pengujian aktivitas antioksidan menggunakan metode 
DPPH sedangkan penentuan kadar fenol total atau total phenol count (TPC) dari ekstrak etanol dan ekstrak air cakar U. gambir menggunakan folin ciocalteu yang selanjutnya diukur secara spektrofotometri.

\section{METODE PENELITIAN}

Bahan dan alat yang digunakan antara lain adalah etanol $70 \%$ p.a, akuades, sampel cakar U. gambir yang diambil di hutan sekitar kampus Universitas Tanjungpura Pontianak Kalimantan Barat, DPPH, folin ciocalteu, spektrofotometri dan peralatan gelas secara umum. Pelaksanaan penelitian dilakukan di Laboratorium Kimia Jurusan Kimia Fak. MIPA Universitas Tanjungpura. Ekstraksi dilakukan dengan metode maserasi seperti yang dilakukan oleh Warsidah, dkk [9] yaitu sebanyak masing-masing 500 gram cakar U. gambir yang terlebih dahulu dikeringkan dan diserbukkan, masing-masing sampel ditambahkan dengan etanol $70 \%$ dan akuades hingga serbuk terendam selama $2 \times 24$ jam pada suhu ruang, filtratnya lalu dipisahkan dan dilakukan remaserasi pada ampasnya selama 3 x 24 jam sampai terjadi kesetimbangan di mana warna cairan penyari tidak berwarna pekat lagi. Filtrat yang telah dikumpulkan selanjutnya diuapkan dengan rotavapor (rotary evaporator) pada suhu didih pelarut (etanol suhu $70^{\circ} \mathrm{C}$ dan air $100^{\circ} \mathrm{C}$. Sisa pelarut dapat diuapkan kembali menggunakan waterbath suhu $50^{\circ} \mathrm{C}$ dan siap untuk dilakukan pengukuran aktivitas antioksidan dan angka total fenol.

\section{Prosedur Pengujian Antioksidan}

Pengujian antioksidan dilakukan dengan menentukan $\lambda_{\text {maks }}$ larutan DPPH. Dibuat larutan dari ekstrak etanol dan ekstrak air dari cakar gambir dalam konsentrasi 20, 40, 80,100 dan $120 \mu \mathrm{g} / \mathrm{mL}$, serta larutan kontrol positif vitamin $\mathrm{C}$ dalam konsentrasi 2, 4, 6, 8 dan $10 \mu \mathrm{g} / \mathrm{mL}$. Setelah itu, diambil masingmasing $1 \mathrm{~mL}$ dari larutan sampel ekstrak etanol, ekstrak air cakar gambir dan kontrol vit C, ditambahkan DPPH 0,1 mM sebanyak $2 \mathrm{~mL}$, diinkubasi tanpa cahaya selama 30 menit pada suhu kamar dan dilanjutkan dengan pengukuran absorbansi pada $\lambda_{\text {maks }} 516 \mathrm{~nm}$. Persentase aktiviitas antioksidan ditentukan dengan meghitung data absorbansi menggunakan persamaan :

\%inhibisi $=\frac{\text { A kontrol }- \text { A sampel }}{\text { A kontrol }}$
Keterangan:
A kontrol: Absorbansi kontrol
A sampel: Absorbansi sampel

\section{Prosedur Penentuan Total Fenol \\ Penentuan $\lambda_{\text {maks }}$}

Dibuat stok larutan asam galat 100 ppm, sebanyak $1 \mathrm{~mL}$ dipindahkan ke labu ukur $10 \mathrm{~mL}$, lalu ditambahkan pereaksi Folin-Ciocalteu $1 \mathrm{~mL}$, ditambahkan $\mathrm{Na}_{2} \mathrm{CO}_{3} \quad 10 \%$ sebanyak $4 \mathrm{~mL}$, didiamkan dan 15 menit kemudian dilakukan pengukuran $\lambda$ maks larutan tersebut dengan panjang gelombang 700-800 $\mathrm{nm}$ menggunakan spektrofotometer sinar tampak.

\section{Pembuatan Kurva Kalibrasi}

Diambil masing-masing sebanyak 1, 3, 5 dan $7 \mathrm{~mL}$ dari larutan stok asam galat 100 ppm, diencerkan dengan dengan akuades sampai $10 \mathrm{~mL}$ dalam labu takar sehingga diperoleh larutan konsentrasi 10, 30, 50 dan $70 \mathrm{ppm}$. Sebanyak $0.2 \mathrm{~mL}$ dari masng-masing konsentrasi ini, ditambahkan dengan $1 \mathrm{~mL}$ reagen Folin Ciocalteu dalam labu ukur $10 \mathrm{~mL}$. Selanjutnya ditambahkan Na2CO3 $10 \%$ sebanyak $3 \mathrm{~mL}$ dan dibiarkan pada suhu kamar sampai 30 menit. Data hasil pengukuran absorbansi pada panjang gelombang maksimum dibuat kurva linier dengan persamaan y $=$ $\mathrm{bx}+\mathrm{a}$.

\section{Penentuan Kandungan Fenolik Total dengan Metode Folin-Ciocalteu}

Ekstrak etanol dan ekstrak air dari cakar gambir Sebanyak 0,1 mL dan 7,9 mL akuades, ditambahkan reagen Folin-Ciocalteulalu sebanyak $0.5 \mathrm{~mL}$ dalam labu takar $10 \mathrm{~mL}$. Setelah itu, ditambahkan dengan sebanyak 1.5 mL Na2CO3 $10 \%$ dibiarkan sampai 1 jam dalam suhu kamar. Pengukuran absorbans pada $\lambda$ maks menggunakan spektrofotometer UV-Vis dengan 3 replikasi. Kadar fenol yang dihasilkan ekuivalen dengan sejumlah asam galat/g sampel segar.

\section{HASIL DAN PEMBAHASAN}

Cakar gambir tumbuh pada daerah ketiak daun dan ketiak ranting, bentuknya melengkung denan ujung runcing. Sampel cakar gambir dalam penelitian ini terlebih dahulu dikeringanginkan untuk menguapkan 
airnya sampai diperoleh kadar air sekitar 10\% kemudian diserbukkan untuk memperluas permukaan sampel, sehingga pelarut pengekstrak dapat lebih mudah berpenetrasi masuk ke dalam sel dan menyari lebih banyak zat aktif dari sampel tersebut. Pemilihan etanol $70 \%$ dan akuades sebagai cairan penyari zat aktif dalam serbuk cakar gambir adalah karena tidak beracun dan tidak berbahaya, sehingga ekstrak yang dihasilkan dengan mudah dan aman dapat diaplikasikan pada bahan makanan atau sediaan herbal yang dikonsumsi secara oral.

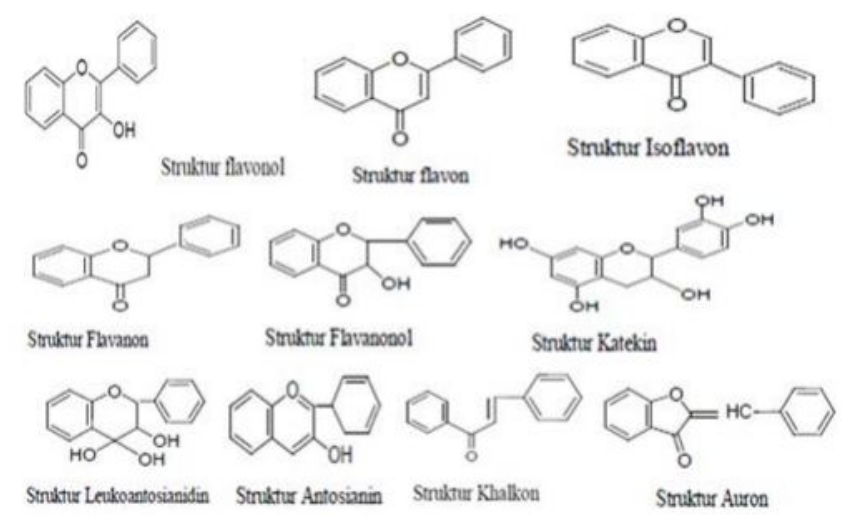

Gambar 1. Berbagai struktur senyawa fenol [17]

Selain itu, berdasarkan penelitian sebelumnya bahwa daun tanaman gambir memiliki kandungan fenol yang tinggi antara lain_senyawa katekin dan turunannya, di mana struktur molekulnya terdiri atas 2 cincin aromatik dan lebih dari 1 gugus hidroksil, ditunjukkan dalam gambar 2. Menurut Robinson [18], senyawa fenol yang diekstraksi dari tanaman memiliki sifat polar dengan adanya gugus hidroksil pada strukturnya tersebut, sehingga pelarut etanol $70 \%$ dan akuades yang juga bersifat polar adalah pilihan yang tepat untuk mengekstraksinya.

Meskipun beberapa metode pengujian aktivitas antioksidan secara in-vitro seperti FRAP (Ferric Reducing Ability of Plasma), TRAP (Trapping Antioxidant Parameter), conjugated diene dan penangkapan radikal hidroksil [18], tetapi pengujian antioksidan dari ekstrak etanol cakar gambir dalam penelitian ini dilakukan dengan menggunakan DPPH sebagai sumber radikal bebas dan pengukuran kemampuan senyawa aktif dari ekstrak etanol gambir dalam memblock radikal dari DPPH diukur dengan spektrofotometer UV. Metode DPPH lebih sering digunakan dalam pengujian antioksidan, karena lebih mudah, efektif, dan lebih cepat pengerjaannya.
Kepekaan zat aktif dalam sampel terhadap penambahan radikal DPPH cukup tinggi yang ditunjukkan dengan perubahan spectrum UV yang terukur pada spektrofotometer. Umumnya profil dan potensi antioksidan dari sampel ekstrak tumbuhan sangat mudah diketahui dengan menggunakan metode DPPH ini [19].

Pokorny et al., [20] menyatakan bahwa senyawa fenolik antara lain seperti flavonoid, diterpen fenolik dan asam fenolik memiliki potensi antioksidan yang kuat. Menurut Niki dan Noguchi [21], mekanisme antioksidan dari senyawa fenolik terutama flavonoid antara lain adalah :

1. Pengikatan radikal bebas dari lingkungan ataupun yang produk dari peroksidasi lipid (R', RO', ROO'), melalui transfer elektron (atom hidrogen).

2. Menghambat reaktivitas senyawa dalam memproduksi katalis transisi metal melalui proses pengkhelatan.

3. interaksi antar antioksidan

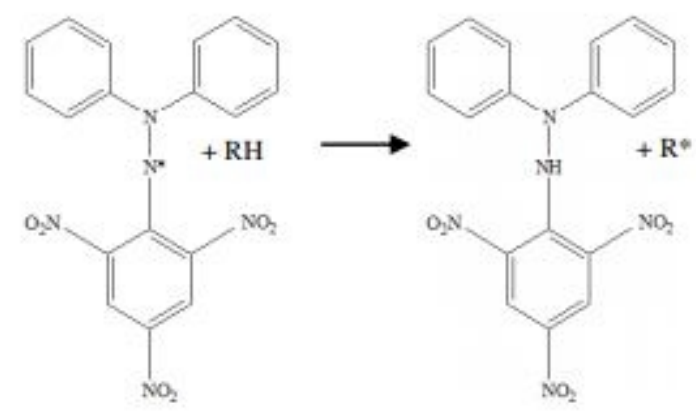

Gambar 2. Reaksi reduksi 1,1-diphenil-2- pikrilhidrazil (DPPH) dari antioksidan [22]

Senyawa fenolik dalam ekstrak etanol cakar gambir adalah senyawa organik yang memiliki aktivitas antioksidan, dengan cara mendonorkan atom hidrogen yang dimilikinya kepada 1,1-diphenyl-2pikrilhidrazil (DPPH). Menurut Prakash, dkk [23] bahwa penggunaan metode DPPH lebih luas dalam menentukan potensi antioksidan yang dapat berperan sebagai donor elektron ataupun hidrogen. Pada reaksi antara senyawa aktif dalam sampel dengan DPPH sebagai radikal bebas, akan terjadi penangkapan radikal bebas DPPH dari senyawa aktif antioksidan yang akan menyebabkan terjadinya elektron yang berpasangan pada radikal DPPH sehingga warna DPPH memucat (penghilangan warna). Penghilangan atau pemucatan warna akan sebanding dengan banyaknya elektron yang dipakai untuk berpasangan. 
Dehpour dkk [23] dalam penelitiannya menegaskan bahwa keberadaan senyawa antioksidan akan merubah warna larutan warna ungu gelap (DPPH) menjadi lebih pucat (warna kuning), dan semakin besar kemampuannya untuk menangkap radikal bebas DPPH, maka intensitas warnanya makin pudar [24].

Hasil perhitungan aktivitas antioksidan dan kadar total fenol dalam ekstrak cakar gambir dapat ditunjukkan pada gambar 3. Berdasarkan parameter Molyneux P [25] kandungan antioksidan dari ekstrak etanol cakar gambir tergolong sangat kuat karena lebih kecil dari $50 \mu \mathrm{g} / \mathrm{mL}$ sedangkan ekstrak air termasuk dalam kategori kuat karena berada pada range antara $50-100 \mu \mathrm{g} / \mathrm{ml}$. Pelarut etanol dan pelarut air memiliki kepolaran yang hampir sama, digolongkan sebagai pelarut polar sehingga digunakan sebagai larutan penyari dalam penelitian ini. Senyawa fenol dalam bahan alam sangat efektif diekstraksi dengan menggunakan pelarut polar, contohnya etanol dan air [26]

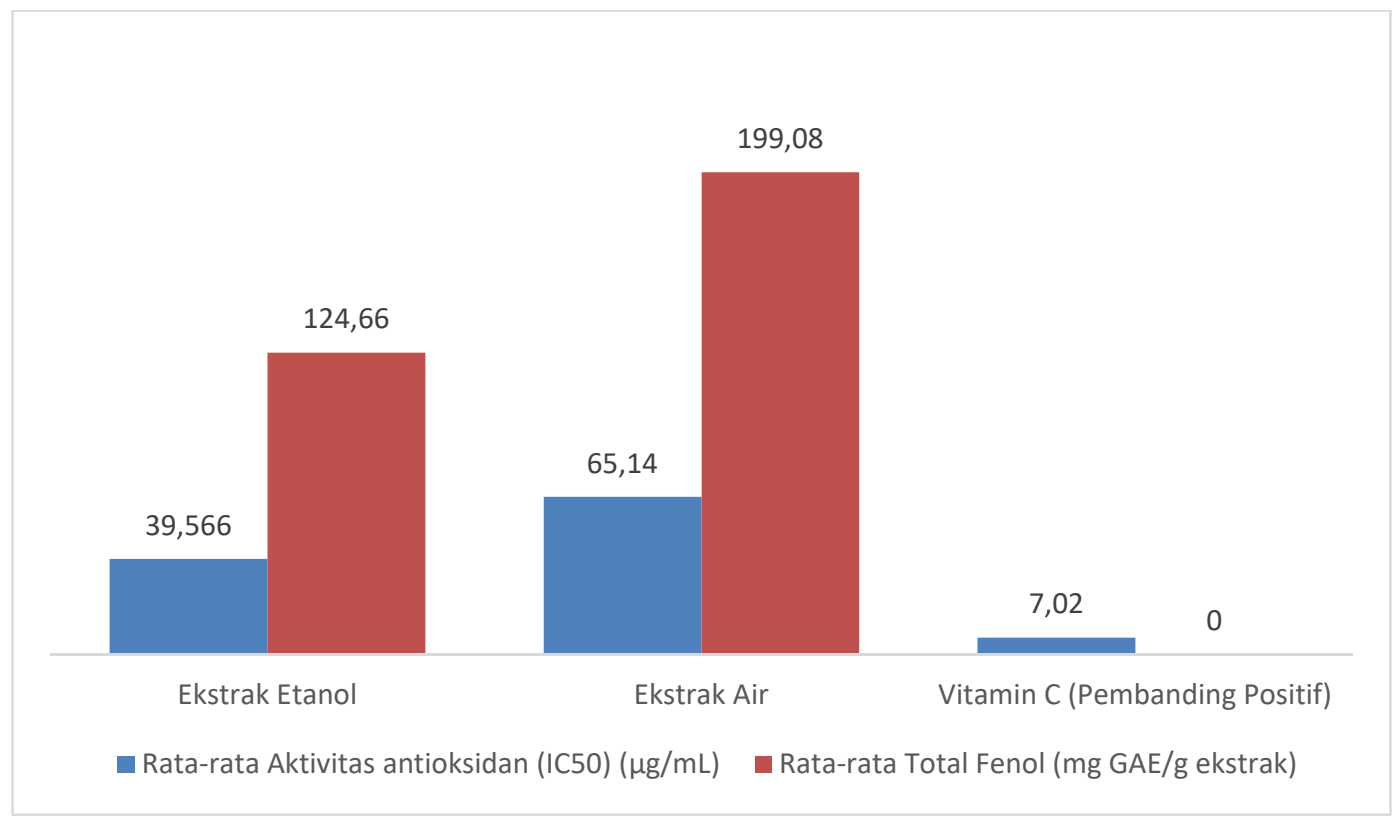

Gambar 3. Diagram aktivitas antioksidan (IC50) dan kandungan total Fenol dari ekstrak cakar gambir

Afinitas setiap senyawa organik dari suatu spesimen tanaman akan berbeda berdasarkan polaritas pelarut sehingga untuk mengekstraksi senyawa-senyawa organik tersebut, termasuk fenolik dalam suatu jaringan tanaman direkomendasikan menggunakan pelarut dengan tingkat polaritas yang berbeda. Dari tabel 1 menunjukkan bahwa kandungan total fenol dalam ekstrak air cakar gambir lebih tinggi dibanding dengan ekstrak etanolnya. Hal ini kemungkinan disebabkan oleh kepolaran yang sangat tinggi dari pelarut air dengan konstanta dielektrik sebesar 80,37 dibandingkan dengan etanol yang memiliki konstanta dielektrik sebesar 24,30, sehingga pelarut air memiliki kemampuan untuk mengekstraksi semua senyawa fenol termasuk senyawa kompleks fenol yang terdapat dalam cakar gambir tersebut [27].
Sebaliknya pada ekstrak etanol yang kepolarannya lebih rendah daripada air kandungan fenolnya lebih kecil, karena selektivitasnya lebih rendah dalam mengekstraksi senyawa fenol dari suatu matriks.

Menurut Prior, dkk [28], senyawa fenol dapat dideteksi dengan pelarut Folin-Ciocalteau di mana pada reaksi menunjukkan terjadinya perubahan warna kuning dari larutan menjadi warna biru tua. Komposisi dari Folin-Ciocalteau adalah asam fosfomolibdat-fosfotungsat akan direduksi oleh senyawa feol dalam sampel sampai terbentuk senyawa kompleks warna biru dari molibdenum tungstate. Intensitas warna biru hasil reaksi setara dengan konsentrasi ion fenolat yang terjadi, yang menunjukkan besaran atau nilai kandungan senyawa fenolnya. 


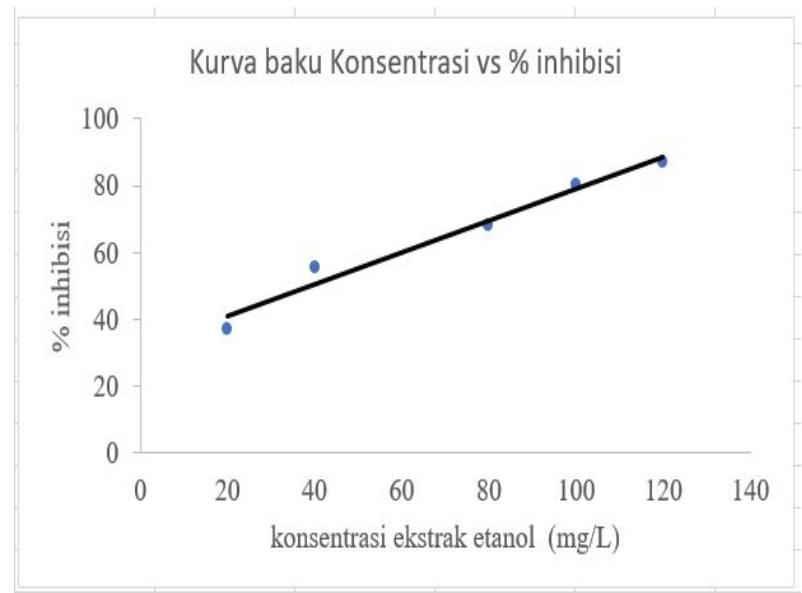

(a)

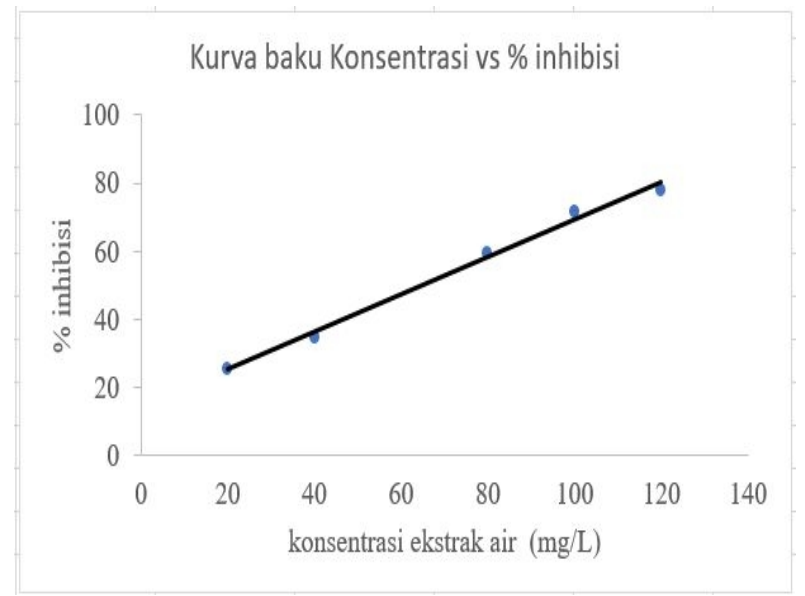

(b)

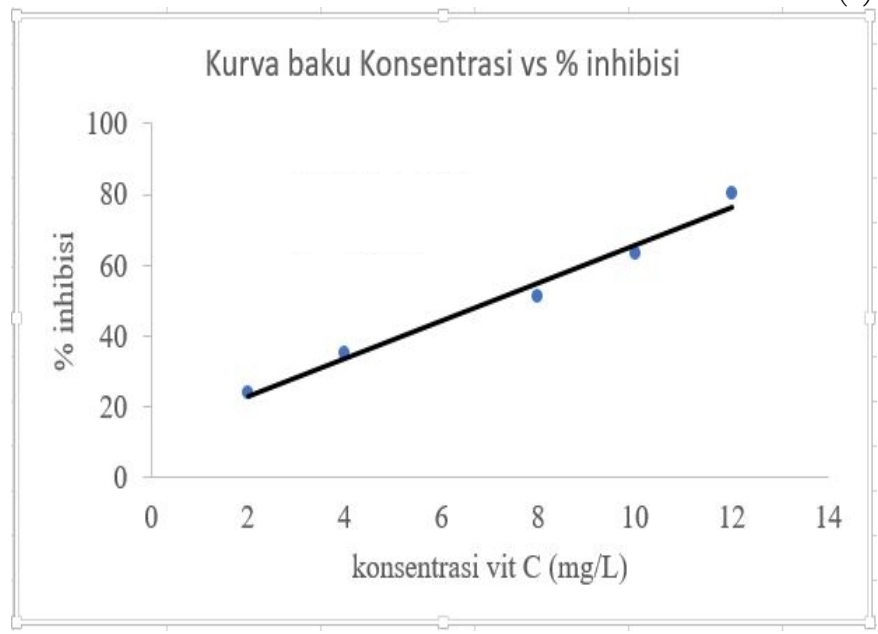

(c)

Gambar 4. Kurva baku "Konsentrasi vs \% inhibisi” (a) esktrak etanol; (b) ekstrak air; (c) vitamin C

Potensi antioksidan dari ekstrak etanol dan ekstrak air cakar gambir termasuk dalam kategori antioksidan sangat kuat dan antioksidan kuat. Nilai IC50 ekstrak etanol cakar gambir lebih besar dari pada ekstrak airnya karena kemungkinan kandungan komponen aktif pada ekstrak etanol tergolong fenol sederhana ataupun dari jenis tannin yang terkondensasi dan memiliki aktivitas antioksidan yang lebih kuat dibandingkan dengan senyawa fenol yang terikat dengan senyawa kompleks dalam ekstrak airnya. Efek antioksidan terjadi dengan mekanisme pelepasan atom hidrogen dari kandungan fenol dari cakar gambir untuk berpasangan dengan elektron bebas (radikal) yang terdapat dalam DPPH (Gambar 3). Tomsone, dkk [29] menyatakan bahwa aktivitas penangkal radikal bebas dari DPPH dari suatu senyawa yang diekstraksi dalam tanaman atau bahan pangan akan berbeda tergantung pelarut yang digunakan dan karakteristik dari suatu bahan pangan. Gambar 4 menunjukkan kecenderungan meningkatnya persen penghambatan radikal bebas DPPH berbanding lurus dengan konsentrasi ekstrak etanol dan ekstrak air cakar gambir serta konsentrasi Vitamin C sebagai antioksidan pembanding dalam penelitian ini. Besarnya aktivitas dari penangkalan radikal bebas DPPH akan tergantung pada penambahan ekstrak hingga batas konsentrasi tertentu, dan akan mengalami penurunan kembali dengan penambahan konsentrasi yang lebih besar [30].

\section{KESIMPULAN}

Dari hasil penelitian ini dapat disimpulkan kandungan fenol ekstrak air dari cakar gambir $199.08 \mathrm{mg}$ GAE/g ekstrak lebih besar daripada ekstrak etanolnya 124.66 mg GAE/g ekstrak, aktivitas antioksidan (IC50) 
ekstrak etanol cakar gambir $39.566 \mu \mathrm{g} / \mathrm{mL}$ lebih besar daripada aktivitas antioksidan (IC50) ekstrak airnya sebesar $65.140 \mu \mathrm{g} / \mathrm{mL}$, dengan IC50 dari antioksidan pembanding Vitamin C sebesar $7.02 \mu \mathrm{g} / \mathrm{mL}$.

\section{DAFTAR PUSTAKA}

[1] Young, I. S., Woodside, J. V. 2001. Antioxidants in health and disease. J Clin Pathol. 54:176-86.

[2] Sivanandham, V. 2011. Free Radicals In Health And Diseases - A Mini Review, Pharmacologyonline 1: 1062-1077.

[3] Jang, H.D., Chang, K.S., Huang, Y.S., Hsu, C.L., Lee, S.H. and Su, M,S. 2007. Principal Phenolic Phytochemicals and Antioxidant Activities of Three Chinese Medisinal Plants. Food Chemistry 103: 749_ 756.

[4] Buyukokurodlu, M.E, Ggulcin, I., Oktay, M., Kufreviodlu, O.I. 2001. In Vitro Antioxidant Properties of Dantrolene Sodium, Pharmacol Res., 44, 491-495.

[5] Novanty N, Pangkahila W, Ayu DN. 2021. Administration of Ethanol Extract of Bajakah Tampala (Spatholobus littoralis Hassk) Stem Decreased Reactive Oxygen Species, Visceral Fat and Body Weight of Obese Rats, Neurologico Spinale Medico Chirurgico, 4(1), hal. 32-36.

[6] Fernández-Sánchez A, Madrigal-Santillán E, Bautista M. 2011. Inflammation, Oxidative Stress, and Obesity. International Journal of Molecular Sciences. 12(5) pp. 3117-3132.

[7] Ozsoy, N., Can, A., Yanardag, R. and Akev, N. 2008. Antioxidant activity of Smilax excelsa L. leaf extracts. Food Chemistry 110: 571-583. Rismana, E., Ningsih, S. \& Fachrudin, F., 2017. In Vitro Study of Xanthine Oxidase Inhibitory of Gambir (Uncaria gambir) Hunter Roxb extracts. Pharmacogn J, 9(6), pp. 862-865

[8] Kumaran, A., Karunakaran, R. 2006. Nitric Oxide Radixal Scavenging Active Components From Phyllanthus Emblica L. Plant Foods Hum. Nutr, 61, 1-5.

[9] Warsidah, Fadly, D., Bohari. 2020. Antibacterial and Anti-inflammatory Activities of Ethanol Extract Obtained from The Hooks of Uncaria tomentosa (Wild. Ex Schult) DC Originated Kalimantan, Indonesia. Syst. Rev. Pharm. 11, 65-70.

[10] Mega Sari Juane Sofiana, Warsidah, Dodi Iskandar. 2020. Cytotoxicity Activities of Ethanol Extract of Hooks Uncaria tomentosa West Kalimantan. The Journal of Food and Medicinal Plants. 1 (1) hal. 1-4.

[11] Iskandar, D, Warsidah. 2020. Qualitative Phytochemical Screening and Antioxidant Activity of Ethanol Root Extract of Spatholobus littoralis Hassk.
The Journal of Food and Medicinal Plants. 1 (1) hal. 13-15.

[12] Saputera, Mochammad MA, Marpaung, T. W. A., \& Ayuchecaria, N. 2019. Konsentrasi Hambat Minimum (KHM) Kadar Ekstrak Etanol Batang Bajakah Tampala LA (Spatholobus littoralis Hassk) Terhadap Bakteri Escherichia Coli Melalui Metode Sumuran. Jurnal Ilmiah Manuntung, 5(2), 167

[13] Sazwi, N. N., Nalina, T. \& Rahim, Z. H. A. 2013. Antioxidant and Cytoprotective Activities of Piper Betle, Areca catechu, Uncaria Gambir and Betel Quid With and Without Calcium Hydroxide. BMC Complementary and Alternative Medicine, Volume 13, pp. 351.

[14] Amir, M. et al. 2012. Phytochemical Analysis and In Vitro Antioxidant Activity of Uncaria Gambir. International Journal of Green Pharmacy, Volume 6, pp. $67-72$

[15] Anggraini, T., Tai, A., Yoshino, T. \& Itani, T. 2011. Antioxidative Activity and Catechin Content of Four Kinds of Uncaria Gambir Extracts from West Sumatra, Indonesia. African Journal of Biochemistry Research, 5(1), pp. 33-38.

[16] Melia, S., Novia, D. \& Juliyarsi, I. 2015. Antioxidant and Antimicrobial Activities of Gambir (Uncaria gambir Roxb) Extracts and Their Application in Rendang. Pakistan Journal of Nutrition, 14(12), pp. 938-941.

[17] Robinson, T. 1995. Kandungan Organik Tumbuhan Tinggi, diterjemahkan oleh Kokasih Padmawinata, ITB, Bandung, pp. 47.

[18] Shivaprasad, H.N., Mohan, S., Kharya, M.D.,Shiradkar, M.R.,dan Lakshman, K., 2005. In-Vitro Models for Antioxidant Activity Evaluation: a review, http://www.pharmainfo.net/reviews/vitro-modelsantio

[19] Shalaby, E.A., Shanab, S.M.M. 2013. Antioxidant Compounds, Assays of Determination and Mode of Action. African Journal of Pharmacy and Phamacology 7(10):528-539.

[20] Pokorny, J., Yanishlieva, N., dan Gordon, M. 2001. Antioxidant in Food; Practical Applications, Wood Publishing Limited, Cambrodge, England, pp. 1-123.

[21] Niki, E., dan Noguchi, N. 2000. Evaluation of Antioxidant Capacity : What Capacity is Being Measured by Which Method, IUBMB Life, 50, 323329.

[22] Ningsih, S. et al. 2014. Evaluation of Antilipid Peroxidation Activity of Gambir Extract on Liver Homogenat In Vitro. Int.J. PharmTech Res, 6(3), pp. 982-989. 
[23] Prakash, A., Rigelhof, F., dan Miller, E. 2001. Antioxidant Activity. Medalliaoan Laboratories, Vol 19 no : 2, 1-4

[24] Dehpour, A.A., Ebrahimzadeh, M.A., Nabavi, S.F. 2009. Antioxidant Activity of Methanol Extract of Ferula Assafoetida and its Essential Oil Composition. Grasas Aceites, 60 (4), 405-412.

[25] Dhalimi A. 2006. Permasalahan Gambir (Uncaria gambir) di Sumatera Barat dan Alternatif Pemecahannya. Jurnal Perspektif, 5(4): 46-59.

[26] Kuncahyo, I., dan Sunardi. 2007. Uji Aktivitas Ekstrak Belimbing Wuluh (Averhoa bilimbi L.) terhadap DPPH, SNT, 1-9.

[27] Sirwutubun, M., Ludong, M. M., \& Rawung, D. 2016. Pengaruh Konsentrasi Etanol Terhadap Karakteristik Ekstrak Pewarna Alami Buah Merah (Pandanus Conoideus Lamk.) Dan Aplikasinya Pada Produk Pangan. In COCOS, Vol. 7, No. 5.

[28] Prior, R.L., Wu, X. \& Schaich, K. 2005. Standardized Methods for The Determination of Antioxidant Capacity and Phenolics in Foods and Dietary Supplements. Journal of Agricultural and Food Chemistry. 53(10), 4290-4302

[29] McDonald, S., Prenzler, P.D., Antolovich, M. and Robards, K. 2001. Phenolic Content and Antioxidant Activity of Olive Extracts. Food Chemistry, 73: 73- 84.

[30] Molyneux, P. 2004. The Use of The Stable Free Radical Diphenylpicrylhydrazyl (DPPH) for Estimating Antioxidant Activity, Songklanakarin, J.Sci. Technol., 26 (2), 211-219. 